\title{
The neglected governance challenges of agricultural mechanisation in Africa - insights from Ghana
}

\author{
Thomas Daum $^{1} \cdot$ Regina Birner ${ }^{1}$
}

Received: 27 June 2016 / Accepted: 31 July 2017 / Published online: 20 September 2017

(C) The Author(s) 2017. This article is an open access publication

\begin{abstract}
After decades of neglect, agricultural mechanisation is back on the development agenda in Africa. Taking the mechanisation efforts of Ghana as an example, this paper analyses the governance challenges involved in government and private sector efforts to promote mechanisation in smallholderbased farming systems. To identify these governance challenges, this paper develops a conceptual framework that combines the agricultural innovation system approach with the concepts of New Institutional Economics. Two qualitative empirical methods were used to apply the framework: the Net-Map technique, which is a participatory mapping tool, and expert / key informant interviews. The results show that next to well-known problems such as market failures concerning access to spare-parts supplies and credit, mechanisation is constrained by missing institutions, particularly those that would be required to ensure adequate skill development of tractor-operators and technicians. In addition, exchange rate fluctuations and impeding customs practices prevent stronger private sector involvement in mechanisation. Governance challenges such as political interest and elite capture were found to limit the effectiveness of government imports of tractors and machinery. The findings suggest that instead of focusing on the supply of subsidised machinery, the government could be more effective by investing in institutional development to strengthen the agricultural innovation system for mechanisation and to support emerging private sector initiatives.
\end{abstract}

Thomas Daum

thomas.daum@uni-hohenheim.de

Regina Birner

regina.birner@uni-hohenheim.de

1 Institute of Agricultural Science in the Tropics,

Hans-Ruthenberg-Institute, University of Hohenheim, Wollgrasweg 43, 70599 Stuttgart, Germany
Keywords Agricultural mechanisation · Governance challenges $\cdot$ Agricultural innovation system $\cdot$ Smallholder farming $\cdot$ AMSEC $\cdot$ Africa

\section{Introduction}

In the past decade, agricultural mechanisation has returned to the development agenda in Africa. This change is reflected in major mechanisation efforts in a range of African countries, e.g., Kenya, Nigeria, Tanzania, Mali, Uganda and Zimbabwe (Diao et al. 2016; Mrema et al. 2008). The new emphasis marks a shift in development strategy bias towards the provision of land saving technologies such as fertilisers (Nin-Pratt and McBride 2014; Pingali et al.1987). One reason for this was the "miserable track record" [sic] produced by state-led mechanisation in the 1950s and 1960s (FAO 2015, para. 2). These programmes (machinery imports, hire services and state farms) failed because of governance challenges such as rent seeking and lack of access to spare-parts, qualified operators and technicians. In addition, scholars argued that many of these programmes were not based on a real need for mechanisation (Mrema et al. 2008; Pingali 2007).

There is evidence from various African countries that this last statement is no longer true. Countries with underutilised land resources but increasingly scarce labour, such as Ghana, Tanzania and Mali, are likely to take the avenue towards mechanisation instead of focusing on "Asian-style green revolution technologies" (Deininger and Byerlee 2011, Diao et al. 2014; Nin-Pratt and McBride 2014, p.153). This is in contrast to e.g. Rwanda where labour is abundant and land expansion is associated with high environmental costs (Jayne et al. 2014a). As shown by Binswanger (1986), mechanisation can lead to an expansion of agricultural area, output and even employment if land is available and the demand for agricultural products is 
elastic. Agriculture in the United States in the nineteenth century is an example of such a situation. The second condition (elastic demand) is more likely to apply in Africa now than it was in the past, due to improved market access and (urban) population growth, which has created a rising demand for agricultural products (Ashburner and Kienzle 2011). Farm structures have also changed, and the rise of medium-scale farmers, observed, e.g., by Jayne et al. (2014b), provides new opportunities for machinery service markets. Moreover, there is evidence that both large and smallholder farmers demand mechanisation because trends such as urbanisation and change in farming systems have created critical labour bottlenecks, particularly during land preparation (Ashburner and Kienzle 2011; Diao et al. 2014). ${ }^{1}$ In Ghana, for example, $60 \%$ of smallholders depend upon hired labour. Socio-cultural factors also play a role. Young farmers demand mechanisation services because manual work, which is associated with drudgery and low productivity, makes agriculture unattractive compared with other occupations (Ashburner and Kienzle 2011).

The new emphasis on mechanisation has led to a variety of different initiatives. State-Led programmes that were widespread in the past, such as the distribution of governmentimported subsidised tractors, remain common (Diao et al. 2014; Mrema et al. 2008). However, there is also a strong focus on the private sector, e.g., via government support to private service providers. In addition, the private sector is developing its own initiatives ranging from small-scale entrepreneurs who import used tractors to large-scale international tractor companies, who now aim to develop business models for smallholders in Africa (Diao et al. 2014; Douglas 2014).

In line with the increased interest in mechanisation, scholars have - after years of neglect - also returned to studying this topic. Recent studies have made important contributions to identify the current drivers of mechanisation in Africa (Diao et al. 2014; Nin-Pratt and McBride 2014; Takeshima et al. 2013) and to assessing the effect and profitability of different mechanisation strategies (Benin 2015; Houssou et al. 2014a). However, there has been limited focus on the governance challenges of agricultural mechanisation. Some studies draw attention to challenges such as the need to access credit and to limited knowledge and skill levels, but often these factors are mentioned in passing, and existing studies have not analysed these challenges and their underlying dynamics comprehensively. This is striking given the overwhelming evidence that the neglect of institutional aspects was one major reason for the failure of past mechanisation efforts and that they have large effects on the profitability of mechanisation (as shown by Houssou et al. 2014a).

\footnotetext{
${ }^{1}$ Animal traction (AT) is often challenging in Africa (Pingali 2007) and undermined by competing policies and a backward image (Starkey 2000). In Ghana, AT is constrained, e.g., as children who serve as ploughboys increasingly go to school (Houssou and Kolavalli 2013).
}

This paper aims to contribute to closing this knowledge gap by presenting a case study on the governance challenges of agricultural mechanisation in Ghana. This country has three main farming systems: the South is dominated by cocoa and inter-cropping of maize, plantain and cassava; the Centre is based on maize, rice and yam farming; and the North is characterised by sole cropping of maize, groundnuts and yam (MoFA 2013). According to Benin (2015), $8 \%$ to $16 \%$ of farming area in Ghana is mechanised. Mechanisation is largely used for power-intensive operations such as ploughing, maize shelling and transportation. For the following reasons, Ghana presents a valuable opportunity to study both state- and market-led mechanisation: The government provides imported tractors at subsidised rates to farmers and to private entrepreneurs who run Agricultural Mechanisation Service Centres (AMSECs), which the government has set up in 89 districts (MoFA 2014c). Ghana also has an emerging private market, both for new and for used tractors, that includes provision of tractor services and involves local entrepreneurs and international companies.

Against this background, this paper addresses the following research questions: Are the current mechanisation efforts, which place more emphasis on private sector involvement, likely to overcome the governance challenges inherent in past government-led mechanisation efforts? Which governance challenges of state-led and market-led types of agricultural mechanisation can be identified based on theory, taking especially concepts of the New Institutional Economics into account? What governance challenges must be addressed to avoid the problems of the past and make mechanisation sustainable from an economic, social and environmental perspective? How can an enabling environment for emerging private sector initiatives be created?

To answer these questions, this paper makes a conceptual and an empirical contribution. Moreover, the paper aims to contribute to the development of methods for empirical data collection on governance challenges. At the conceptual level, we developed a framework that combines concepts of New Institutional Economics (NIE) with the Agricultural Innovation System (AIS) approach. NIE stresses the crucial role of transaction costs for economic development and the concept of governance challenges used in this paper is largely based on the NIE literature (Kherallah and Kirsten 2001). NIE developed as a response to the assumption in neo-classical economics that economic agents "operate almost in a vacuum", which refers to an institutional vacuum (Kherallah and Kirsten 2001, p.2). The AIS approach can be used to map all the actors and factors that influence innovation processes (section 2.2.). Combining both approaches allows us to systematically identify the bottlenecks that increase the transaction costs of mechanisation that arise due to governance challenges. To apply this conceptual framework empirically, two qualitative methods of data collection were combined: the participatory mapping 
tool Net-Map and key informant and expert interviews (section 3). By approaching the topic from both a conceptual and an empirical perspective, this paper aims to make a contribution that is not only relevant for Ghana but also for other African countries that are promoting agricultural mechanisation.

The paper proceeds as follows: Section 2 develops the conceptual framework and identifies potential governance challenges based on economic theory and the literature on mechanisation. Research methods are described in Section 3. Section 4 presents the empirical results, which are discussed in Section 5. Section 6 concludes.

\section{Conceptual framework and literature review}

The conceptual framework proposed here consists of two parts. In the first part, concepts of New Institutional Economics are applied to identify governance challenges that can arise from market, government and community failure in agricultural mechanisation. The empirical literature on mechanisation is reviewed to substantiate those governance challenges. In the second part, the concept of the Agricultural Innovation System is applied to agricultural mechanisation to guide the empirical investigation of these governance challenges.

\subsection{Governance challenges of agricultural mechanisation}

To identify the governance challenges of agricultural mechanisation, we consider three basic types of governance structures or institutional settings under which mechanisation services can be provided: the private sector (market governance), the government sector (state governance), and the third sector (community governance). All three types of governance structures face their own challenges. In the area of market governance, these challenges are commonly referred to as market failure. Using the same terminology, we label the governance challenges in the other two sectors "state failure" and "community failure" (Birner and Anderson 2007). The following sections identify the underlying reasons for these failures in the case of agricultural mechanisation.

\subsubsection{Market failure}

Markets fail when they do not reach an allocation of resources that is efficient for the society (Bator 1958). The following reasons can lead to market failures in agricultural mechanisation:

(1) Indivisibility: Tractors are private goods, but unlike many other agricultural inputs (e.g., seeds and fertilisers), they are indivisible and, therefore, involve economies of scale. Operating tractors at an economic scale might be difficult if farms are small and fragmented as past mechanisation efforts have shown (Binswanger 1986; Mrema et al. 2008). Institutional solutions, such as tractor service markets and cooperatives, have helped smallholders to overcome these problems in countries that are now industrialised (see Olmstead and Rhode 1995, for the USA). However, developing these institutional solutions remains difficult as long as capital markets are underdeveloped. Moreover, they are difficult to set up for time-bound operations like ploughing. Diao et al. (2012) have shown how the small window for ploughing operations of only 45 days in the North of Ghana affects the economic viability of service provision (section 4.1.1.). The resulting shortage of suppliers of tractor services can lead to a lack of competition and unequal bargaining power. As Bowles and Gintis (1993) show, agents on the short side of such a non-clearing market (in this case, service providers) can exercise power. The result is higher fees and a lower quality of services than would be the case without market failure. This problem is aggravated by information asymmetry if the farmer has difficulty assessing the quality of the service provided, e.g., the uniformity of the ploughing depth is difficult to assess once the task has been completed. An unequal power relationship combined with the information asymmetry inherent in on-the-spot service markets can level the ground for "hit and run" operators (Fafchamps 2001) who take advantage of smallholder farmers.

(2) Transaction costs and coordination failures: Another reason for market failure is transaction costs and risks, which can lead to failures in complementary supply chains (Kydd and Dorward 2004). For example, access to credit, a precondition to mechanisation, is often limited because of lack of collateral - in Ghana $80 \%$ of the land is customary (USAID 2013) - and the riskiness of rain-fed farming (Binswanger and McIntire 1987; Sacerdoti 2005). Similarly, the problems of a low number of tractors and a lack of spare-parts (or technicians) can reinforce each other due to coordination failures (Kydd and Dorward 2004). Phrased differently, this problem can lead to path dependency and lock-in situations, in which those brands with good access to spareparts will be bought even if their quality is modest.

(3) Public goods and merit goods: Markets fail to provide public goods that are important to support successful mechanisation, such as infrastructure and market stability. Likewise, there is market failure in the provision of merit goods and quasi-public goods. Education is an example of both because it is associated with positive externalities; at the same time, those lacking education will undervalue its benefits because of information asymmetry (Musgrave 1959). Education and training of technicians and tractoroperators will be a merit-good if farmers and tractorowners do not value the benefits of having qualified 
technicians and operators. Farmers and operators might also overlook the need for training required to ensure the safe handling of agricultural machinery. The private sector, e.g., tractor dealers, will not be interested in offering training on generic (not brand-specific) mechanisation topics due to the non-excludability problem. Trained personnel can just switch employers, who then benefit from the investment. As a group, the manufacturers and dealers of tractors face a collective action problem (free-rider problem) of jointly investing in skill development of tractor-operators and technicians.

(4) Externalities: Markets can be distorted because of externalities that disguise the optimal level of mechanisation. Mechanisation has possibly positive externalities such as improved food security. The causal chain starts with increasing timeliness of operations and includes overcoming seasonal labour shortages and cultivating not-yetutilised land (Ashburner and Kienzle 2011). At the same time, mechanisation can have negative externalities such as unemployment, landlessness, environmental problems and an unequal distribution of wealth (Binswanger 1986).

(5) Bounded rationality and information asymmetry: Bounded rationality can also lead to market failures in mechanisation. For example, due to time inconsistencies, tractor-owners might not invest in maintenance and ignore soil erosion. This occurred when farmers in the U.S. in the 1930s ignored soil erosion, which led to the Dust Bowl (Baumhardt 2003). For Ghana, Adjei et al. (2003) and Benin et al. (2013) raised concerns about soil erosion due to disc ploughing as well. A related problem is information asymmetry, which was mentioned above for the case of farmers who hire tractor services. Information asymmetry also affects buyers of tractors. They might fail to evaluate the actual quality of a tractor, which can lead to a downward spiral of price and quality (Akerlof 1970). This "lemon market" problem can be expected to be more pronounced for used tractors. Akerlof (1970) observed this problem for "lemons", a U.S.-American word for (used) cars that turn out to be defective after they have been purchased.

(6) Principle-agent problems: If tractor-owners hire operators, a principle-agent problem occurs. Hiring a tractor operator can occur due to differences in opportunity costs of labour between tractor-owners and hired operators but also due to other reasons such as status considerations or physical conditions. Due to the principle-agent problem, hired operators who are paid per acre can have an incentive to plough as much land as possible in a given time, which will have adverse effects on the maintenance of tractors and the quality of ploughing. Diao et al. (2012) drew attention to the possible occurrence of principleagents problems with regard to maintenance and their consequences on the AMSEC program.

\subsubsection{State failure}

To address market failures in smallholder mechanisation, the government can decide to intervene and subsidise tractors and equipment or to provide tractor services through state agencies. It is ultimately political to decide on the role that government can and should play in mechanisation. However, to make this decision, it is important to understand the different types of "state failure" that public sector activities are confronted with in the field of agricultural mechanisation.

(1) Clientelism, elite capture and political targeting ${ }^{2}$ : Governments can have incentives to provide private rather than public goods in support of mechanisation because private goods can be better targeted to large and politically influential farmers that engage in rent seeking. Importing tractors (a private good) and making them available at subsidised prices is a typical case in point. As a result, past state-led mechanisation concentrated on the import of tractors and neglected capacity development of operators and technicians (Mrema et al. 2008).

Smallholder farmers are not likely to benefit from tractor import programmes because they cannot afford tractors, even when they are highly subsidised, which leads to elite capture. Diao et al. (2012) and Benin (2015) found that distribution of government-imported tractors in Ghana was not transparent and encouraged rent-seeking behaviour. Tractor imports are politically more attractive than is investing in skill development because tractors show short-term effects and generate media attention, which is particularly valuable prior to elections (Birner and Resnick 2010). Benin (2015) also found that $82 \%$ of the AMSECs in Ghana were set up in districts aligned with the same party as the ruling government.

(2) Corruption: In addition to the above problems, the import and distribution of tractors and agricultural machinery by government agencies also lead to various types of corruption problems. Examples are bribes paid by suppliers of machinery in the procurement process or kickback payments paid by farmers who want to receive machinery. The agricultural minister of Nigeria confirmed, "government (...) distribution of tractors was riddled with corruption" (Adesina 2013).

(3) Lack of financial sustainability and crowding out: Related to the previous point is an inclination of politicians to misuse loans as "giveaways", i.e., assets are provided on a loan basis although there is no real

\footnotetext{
${ }^{2}$ Clientelism is the provision of goods and services to targeted groups in expectation of political support. Political targeting is a similar concept but refers to geographic locations (e.g., districts). Elite Capture refers to a situation where "elites" exercise power to channel resources of government programs towards themselves.
} 
intention that the beneficiary will pay back the loan (Banerjee and Duflo 2011, p.161). The government might also lack the capacity to ensure repayment, even if the programmes were not intended to be "giveaways." Both problems pose threats to subsidised lending because the revenue recovery will be insufficient to ensure the financial sustainability of such schemes. For example, Benin et al. (2013) found that the repayment of AMSEC tractors in Ghana was only $35 \%$. Moreover, public spending on tractors can also crowd out private investment. For example, Diao et al. (2014) suggest that imports by the government have retarded the private market in Ghana.

(4) Information problems: Government failures can also emerge because of information problems. The government might fail to choose the appropriate tractors because there is no link between demand and supply. For example, tractors imported during past mechanisation programmes were often too heavy, which led to environmental degradation (Mrema et al. 2008). For Ghana, Diao et al. (2014) raised concerns over the missing link between demand and supply. The disconnection between demand and supply might also lead to a distribution that excludes the most suited beneficiaries.

\subsubsection{Community failure}

Communities can organise themselves to overcome market and state failures. For example, they might purchase and manage a tractor jointly to overcome capital problems and to increase utilisation rates. However, communities also face challenges. Therefore, it is important to understand the reasons that might lead to "community failures".

(1) Collective action problems: The formation of a group that jointly owns and manages a tractor is confronted with the classic free-rider problem of collective action (Ostrom 1990). Tractors require careful operation and regular maintenance, and group members might default on such activities, hoping that the other group members might not realise that. Information asymmetry exacerbates the problem because carefulness in operating and maintaining is not easily observable without high supervision costs. Moreover, the synchronous timing of ploughing and other tractor operations can lead to disputes between group members. More-knowledgeable members of farmer-based organisations (FBOs) might take advantage, e.g., by ensuring that they have better opportunities to use the jointly owned tractor. These problems of collective action will be especially pronounced in situations of low social capital and trust (Fafchamps 2001).
(2) Exclusion: Another problem with FBOs is that they are often dominated by middle-class and wealthy farmers whereas poor farmers and socially marginalised groups often face difficulties in joining such organisations (Birner and Anderson 2007, p.25). Due to rigid gender norms, women often face difficulties in being represented in FBOs; even when they are members, they might have limited opportunities to speak and influence decisions. This situation can restrict women from benefitting from tractor services provided by cooperatives.

(3) Capacity and financial constraints: Purchasing and managing a tractor requires basic understanding of finance and management; thus, FBOs might face capacity problems (Birner and Anderson 2007). Moreover, banks can be reluctant to lend to groups because of a lack of clear responsibilities.

\subsection{Applying the concept of the agricultural innovation system}

A large body of literature on innovation in agriculture has established that innovation processes depend upon a combination of factors: system-wide drivers such as land- and labour-endowments; the characteristics of the technologies; the demand for complementary inputs and training; the institutional environment, e.g., infrastructure and marketing options; and farm characteristics, e.g., farm size, land titles, household members, and risk behaviour (Feder et al. 1985; Sunding and Zilberman 2001).

The concept of the "Agricultural Innovation System" (AIS) has been developed as an analytical framework to address the complexities of innovation processes in agriculture. AIS is defined as the network of "organisations, enterprises, and individuals focused on bringing new products, new processes, and new forms of organisation into economic use, together with the institutions and policies that affect their behaviour and performance" (World Bank 2006, p.vi). In line with the general literature on innovation systems, the main components of an AIS are the knowledge domain (research and education), the business domain (represented by the agricultural value chain) and bridging institutions such as the extension system between the two domains (Spielman and Birner 2008 and the literature quoted there). The AIS concept also emphasises the role of supporting policies and infrastructure and informal institutions, practices, behaviours and attitudes. Figure 1 below displays this concept in an application to mechanisation.

The AIS reflects that innovation is not usually a linear process but often resembles complex "spider webs" full of feedback loops between various aspects and stakeholders (Clark et al. 2003; Ekboir \& Parellada 2002). The AIS concept allows for mapping the different factors and actors that drive 


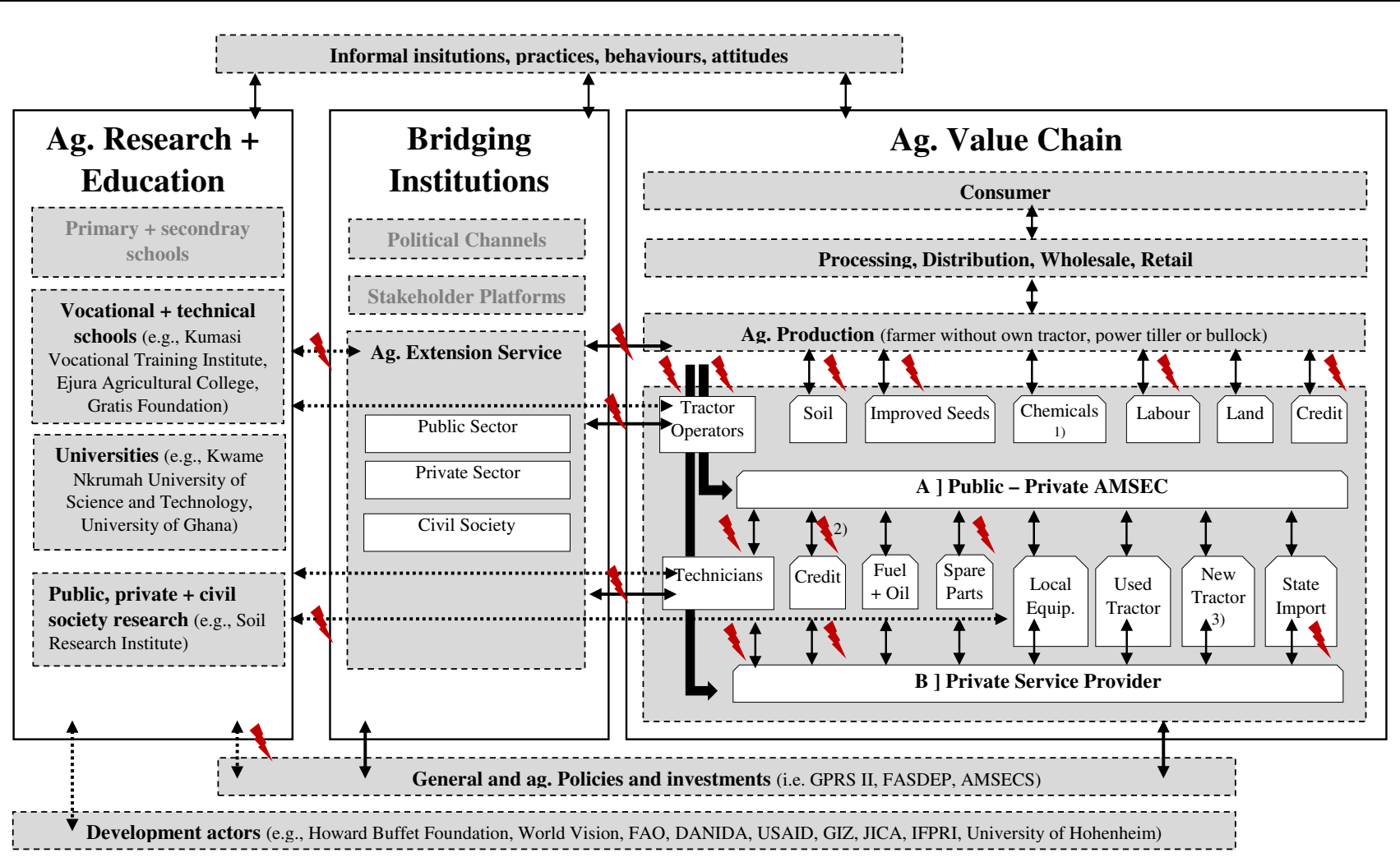

Enabling Environment (macroeconomic stability, rural infrastructure, good governance, business climate, custom policies)

Fig. 1 Mechanisation-AIS. Bottlenecks indicated with flashes. Dotted arrows refer to the complete agricultural research and education domain. Remarks: 1) Pesticides and Fertilisers; 2) Access to AMSEC
Credit Facility; 3) Almost exclusively large (commercial) farms. Informal training not shown due to presentation issues or constrain the adoption of mechanisation. In fact, different authors have previously used the AIS approach to study the adoption of existing technologies, e.g., post-harvest technologies in the Himalayan Hills (Clark et al. 2003) and zero tillage in Argentina (Ekboir \& Parellada 2002).

The AIS concept is used in this paper to identify the role that the private sector, the government and the third sector currently play in mechanisation in Ghana and to analyse where in the innovation system the governance challenges discussed in section 2.1 occur. The analytical goal is to identify which of these governance challenges constitutes the most binding constraints to mechanisation (Section 4.1) and to identify on this basis policy options to address these constraints (Section 5).

\section{Research design and methods}

The previous sections have shown that agricultural mechanisation potentially comprises a multitude of multifaceted governance challenges and numerous stakeholders groups. This complexity makes studying the institutional aspects of agricultural mechanisation challenging from a methodological perspective, particularly because governance challenges are a little-researched area. Against this background, a qualitative explorative research approach is applied, facilitating the discovery of unanticipated findings emerging during the research process. A quantitative survey approach, although useful in many other research areas of agricultural innovation, was not applied here for two reasons. First, a quantitative survey design would not allow the use of interview techniques such as laddering, which are particularly suitable to elicit information on sensitive issues such as governance challenges. Second, the size of most stakeholder groups that play a crucial role in mechanisation is too small for a meaningful quantitative research approach. For example, there are only approximately ten machinery dealers in Ghana. The only stakeholdergroups that would be sufficiently large for a quantitative research approach are farmers and tractor-owners. 
However, their role in mechanisation in Ghana is already well established based on survey research, as shown in the literature review above.

The qualitative research design developed for this study consists of two components:

(1) A mapping of the AIS using a participatory technique called "Net-Map". This method is further explained in Section 3.1. Eight Net-Maps were produced based on group sessions with 6 to 8 participants, resulting in a total of 58 participants (Table 1).

(2) Based on the insights from the Net-Maps, 104 representatives of different stakeholder groups were selected and interviewed, using qualitative in-depth interview techniques, as further detailed in Section 3.2.

In addition to conducting the Net-Maps sessions and the interviews, a range of policy and legal documents and statistical data were reviewed. The study also benefitted from field observations, e.g., of ploughing operations, maintenance and the work of technicians. These observations were conducted in collaboration with agricultural engineers from the Institute of Agricultural Engineering of the University of Hohenheim (Schmitt 2014).

\subsection{Net-map tool}

Net-Map is categorised as a participatory appraisal method and therefore relies on group interaction and visualization. The method was developed by Schiffer (2007) and is particularly suited for analysing the structure and functions of complex systems with multiple actors. A special feature of the NetMap tool is a focus on identifying how stakeholders influence particular outcomes within a wider system. Therefore, this method was found to be particularly suitable to identify the different actors in the AIS and assess their role in the mechanisation process. Another reason for selecting NetMap is that this tool has also been used for analysing governance challenges. For example, Raabe et al. (2010) applied a version called "Process Net-Map" to study the governance challenges of a social safety net program in India. Ilukor et al. (2015) used Net-Map to investigate governance challenges of the provision of veterinary services in Uganda.

Table 1 Overview of Interviews

\begin{tabular}{llll}
\hline & $\begin{array}{l}\text { Number of } \\
\text { interviews }\end{array}$ & $\begin{array}{l}\text { Number of } \\
\text { participants }\end{array}$ & $\begin{array}{l}\text { Total } \\
\text { interviewed }\end{array}$ \\
\hline Group Net-Map-sessions & 8 & $6-8$ & 58 \\
Individual interviews & 104 & - & 104 \\
Total interviews & 112 & - & 162 \\
\hline
\end{tabular}

The authors conducted eight sessions with focus groups in which Net-Maps were produced. The sessions were held in different randomly selected villages in the Upper West Region (Wa East and Sissala West district) of Ghana. Each session included stakeholders such as male and female farmers, tractor-owners, tractor-technicians and tractor-operators. The authors randomly identified tractor-owners from lists of tractorowners provided by tractor-owner-associations in these villages. The same principle was used to identify tractoroperators randomly (via lists of the tractor-operators-association). Farmers were randomly selected via lists provided by the extension offices, and all technicians operating in the respective villages were invited. Stakeholders such as representatives of financial institutions and spare-part dealers were all invited when they existed. The Net-Map procedure was then applied as follows:

In the first step, the participants were asked to discuss the following question:

\section{a) Which stakeholders influence agricultural mechanisation?}

The answers were indicated during the interview process on a large sheet of paper. Then, the participants were asked to discuss the following question:

\section{b) How are stakeholders linked?}

Different types of linkages (e.g., flows of information, money and goods/services) were indicated with arrows between the stakeholders. Thereafter, the participants discussed the following question:

\section{c) Who are the most important stakeholders for agricultural mechanisation?}

The importance of stakeholders was indicated by using playing cards (e.g., the ace and king represented highly influential stakeholders). Based on the map that was produced using this process, the participants then discussed the following two questions:

\section{d) Where are bottlenecks? \\ e) How can bottlenecks be overcome?}

During each step, the participants discussed and explained their opinions (e.g., on why a particular stakeholder is important from their perspective) before a consensus was reached, which was noted on the paper by the moderator. The final NetMaps and the discussions leading to the Net-Maps made it possible to gather valuable insights into the functioning of the AIS for mechanisation. As is common for focus group interviews, the authors ensured that representatives from 
different stakeholder groups participated during each NetMap session so that participating stakeholders could directly crosscheck each other's opinions. From the eight Net-Maps, the authors generated an aggregated Net-Map that was used during the subsequent stakeholder interviews (section 3.2.).

\subsection{Stakeholder interviews}

Based on the Net-Map sessions and the literature review, the authors conducted 104 interviews with respondents who represented all stakeholder groups of the AIS. The details are provided in Table 2. The interviewees were selected with a stratified purpurseful sampling technique as follows. When feasible, a list of all members of a stakeholder group (e.g., machinery dealers) was obtained, and respondents were purposefully selected from this list to capture the diversity of the members of this group. When it was not possible to obtain a complete list, chain-referral sampling (using respondents to identify additional respondents) was used, starting from different entry points. In this case, additional interviews were added until a point of saturation was reached (i.e., until additional interviews did not provide new information on the topics under consideration).

As indicated above, farmers and tractor-owners were included in the qualitative research design to provide additional information that is not yet available from existing survey research. The respondents from these two groups were primarily interviewed in the Upper West region (Wa East and Sissala West district), which is dominated by maize and groundnut farming. This region was selected because farming is sufficiently mechanised to analyse different mechanisation patterns. A smaller subset of local stakeholders was also interviewed in the Volta Region (Hohoe district), which is an agriculturally more diverse farming area. In the Upper West, the operators of all functioning AMSECs were interviewed; in the Volta Region, some AMSEC were randomly chosen. Other stakeholders, such as machinery dealers and research organisations, were interviewed countrywide.

All interviews were semi-structured and open-ended. At the beginning of the interviews, respondents were encouraged to mention freely the institutional challenges they perceived as most important. Later, the interviewer showed the results of the Net-Map session to the respondent and asked him or her to elaborate on specific challenges. All respondents are cited anonymously in this paper, but their categories are indicated using the abbreviations indicated in Table 2. Informed consent was obtained from all individual participants included in the study.

\subsection{Quality assurance}

To ensure scientific rigour and transparency, the authors followed the evaluation standards of qualitative research (see, e.g., Bitsch 2005). Because the data collection addressed sensitive topics, there was special focus on conducting both the Net-Map sessions and the stakeholder interviews in locations that were conducive to this type of research, e.g., by ensuring the absence of government officials during interviews with non-governmental stakeholders. The governance challenges were studied in-depth until a point of saturation was reached (persistent observations). The findings were discussed with research peers (peer debriefing). The emerging findings were also discussed with research participants and experts (member checks). In addition, as seen from the above description, data triangulation and methods triangulation were used to ensure the credibility and confirmability of the results.

\section{Results and analysis}

Subsection 4.1 presents a map and a description of the AIS for mechanisation, the details of which were identified through the Net-Map exercise. In section 4.2, empirical evidence on the institutional bottlenecks that affect different components of the AIS are presented, based on the classification of governance challenges developed in Section 2.1.

\subsection{Agricultural innovation system for mechanisation}

Figure 1 shows the Mechanisation-AIS of Ghana, which captures the different actors that influence agricultural mechanisation. The business domain of the AIS is represented on the right-hand side of the diagram by the agricultural value chain, with the farm as a central element. The knowledge domain is represented on the left-hand side and comprises agricultural research and education institutions. Between the two domains, the bridging institutions are depicted. Zooming in on the agricultural value chain of the AIS shows that most farmers who use mechanisation services do not own tractors. They prefer to use mechanisation service providers, which are private tractor-owners (section 4.1.1) and - to a lesser extentthe public-private AMSECs (section 4.1.2).

\subsubsection{Private service providers}

Most farmers access mechanisation through private service providers who are either medium to large-scale farmers operating between 10 and 50 ha or tractor-owners with other occupations such as teachers, shop owners or retired extension officers who do not have their own farms. Similarly, Houssou et al. (2014b) found that $71 \%$ of the owners possess $>20$ ha and $4 \%<5$ ha (on average 39 ha). Ploughing costs between 40 and 70 US\$ per ha, depending upon the district. These costs correspond to 14 to $23 \%$ of the revenue per ha, assuming an average yield of 1.5 tons/ha of maize and a selling price of 0.2 US $\$ / \mathrm{kg}$. Maize shelling is paid in kind. One $100 \mathrm{~kg}$-bag of maize is charged for ten bags shelled. 
Table 2 Overview of Key-Informant and Expert Interviews. "Frontline stakeholders" are directly involved in the provision and use of mechanisation services. Sixty-eight respondents fell into this group. "Upstream stakeholders" played a more indirect role. They comprised 36 respondents

\begin{tabular}{|c|c|c|c|c|}
\hline & Stakeholder Groups & $\begin{array}{l}\text { Number of } \\
\text { Interviews }\end{array}$ & Abbrev. & Comments \\
\hline \multirow[t]{15}{*}{ Frontline Stakeholders } & Machinery Dealer & 7 & MD1-7 & Representatives of all main machinery dealers. \\
\hline & Machinery Producer & 3 & MP1-3 & $\begin{array}{l}\text { Representatives of international machinery producers } \\
\text { operating in Ghana. These companies primarily act } \\
\text { through machinery dealers, so few of them } \\
\text { were interviewed. }\end{array}$ \\
\hline & Local Manufacturer & 3 & LM1-3 & $\begin{array}{l}\text { A small but diverse subset of local manufacturers from the } \\
\text { Swame Magazine (Kumasi) was interviewed. }\end{array}$ \\
\hline & AMSEC & 9 & AMSEC1-9 & $\begin{array}{l}\text { In the Upper West, representatives of all functioning } \\
\text { AMSECs were interviewed (others were not traceable } \\
\text { or operating). In the Volta Region, AMSECs were } \\
\text { randomly chosen. }\end{array}$ \\
\hline & Farmer & 9 & F1-9 & $\begin{array}{l}\text { In addition to the net-map sessions, } 2-3 \text { farmers were } \\
\text { interviewed in each data-collection district. See } \\
\text { Mensah (2015) for a study on farmer's mechanisation choices. }\end{array}$ \\
\hline & Financial Institution & 5 & FI1-5 & Representatives of rural banks (different scales and concepts). \\
\hline & Tractor Operator & 2 & TO1-2 & $\begin{array}{l}\text { In addition, Florian Schmitt from the Institute of Agricultural } \\
\text { Engineering of the University of Hohenheim interviewed } \\
40 \text { operators. These interviews and his observations were } \\
\text { used for data triangulation. }\end{array}$ \\
\hline & Tractor Owner & 9 & TOW1-9 & $\begin{array}{l}\text { In each data-collection district, } 2-3 \text { owners were interviewed } \\
\text { in addition to the net-map sessions. See Chapoto et al. (2014) } \\
\text { for a quantitative study on tractor-ownership. }\end{array}$ \\
\hline & Spare-parts Dealer & 3 & SPD1-3 & Representatives of all main private spare-part dealers. \\
\hline & Tractor Operator Association & 3 & TOA1-3 & $\begin{array}{l}\text { The chairman of the association in each data-collection } \\
\text { district was interviewed. }\end{array}$ \\
\hline & Tractor Owner Association & 3 & TOWA1-3 & $\begin{array}{l}\text { The chairman of the association in each data-collection } \\
\text { district was interviewed. }\end{array}$ \\
\hline & Farmer-Based Organisation & 2 & FBO2 & $\begin{array}{l}\text { In one data-collection district, representatives of two } \\
\text { farmer-based organizations were interviewed. }\end{array}$ \\
\hline & Tractor Technician & 4 & TT1-4 & $\begin{array}{l}\text { "Road-side"-technicians interviewed in addition to the } \\
\text { net-map session. In the two data-collection districts in } \\
\text { the Upper West, all technicians were interviewed. The } \\
\text { only technician in the regional capital of the Upper } \\
\text { West was interviewed. }\end{array}$ \\
\hline & Used Tractor Importer & 4 & UTI1-4 & Representatives of all main used-tractor-importers. \\
\hline & Processing Company & 3 & PC1-3 & $\begin{array}{l}\text { Representatives of processing companies working within a } \\
\text { nucleus farmers' scheme were interviewed because } \\
\text { they also finance tractors. }\end{array}$ \\
\hline \multirow[t]{4}{*}{ Upstream Stakeholders } & Government & 11 & G1-11 & $\begin{array}{l}\text { Key representative from the Agricultural Engineering and } \\
\text { Service Division (MoFA), which operates the AMSEC and } \\
\text { representatives of the local MoFA / agricultural extension } \\
\text { system in each data-collection district. }\end{array}$ \\
\hline & International Organisation & 15 & IO1-15 & $\begin{array}{l}\text { Representative of all main international organisations } \\
\text { (e.g., development organisations) working on } \\
\text { agricultural mechanisation. }\end{array}$ \\
\hline & Research \& Education & 10 & RE1-10 & $\begin{array}{l}\text { Representatives of all main research and education bodies } \\
\text { working on agricultural mechanisation and/or Conservation } \\
\text { Agriculture were interviewed. }\end{array}$ \\
\hline & Total Interviews & 104 & & \\
\hline
\end{tabular}

According to the interviews, service providers plough between 80 and 320 ha per season and service between 50 and 300 farmers of which approximately half are smallholders. Most tractor-owners bought their tractors from dealers that trade used tractors. These imported approximately 3000 used tractors in the last decade (CEPS 
2012). Used tractors cost approximately 10,000 US $\$$. Tractors come from across Europe and are often in poor condition. Therefore, two old tractors are often used to assemble one functioning tractor. In contrast, private dealers of new tractors such as Massey Ferguson and John Deere almost exclusively sell to large (commercial) farms. Prices for small tractors range from 10,000 to 23,000 US\$. ${ }^{3}$

Many tractor-owners are organised in associations that fix ploughing prices. They also enforce fees for migratory service providers coming from areas with different rainfall patterns. These migratory providers create more competition and prevent local tractor-owners from servicing only large, easily accessible farms, and their presence leads to lower prices despite the fees that local tractor-owners charge. ${ }^{4}$

The evidence on collusion to decide prices jointly and the ability to charge fees indicates that the private service market is not fully competitive, representing the governance challenge of short-side power in non-clearing markets (section 2.1.1). However, the fact that service providers from other regions can enter this market indicates that neither is it fully controlled. Moreover, lack of farmers' access to financial services is likely to constrain the effective demand for tractor services, which can limit the ability of service providers to exploit fully a situation of market power. The evidence collected for this study indicates that provision of services is profitable for tractor-owners unless serious breakdowns occur. ${ }^{5}$

Table 3 shows the Cost-Benefit Analyses of a typical tractor owner in the Upper West (Wa East District) under different scenarios. The analyses are calculated in US dollars. Annual Profit and Internal Rate of Return are based on a 10-year investment period.

The analysis confirms the opinion voiced by farmers that maize shelling is highly profitable. This opinion can be illustrated by not including maize shelling in the CBA of the service provider (Scenario 1); doing so leads to a drop in the internal rate of return from 27 to $11 \%$. Some tractor-owners even reported that the only purpose of providing ploughing services is to ensure the shelling business. Because shelling occurs after the harvest when it can be paid in-kind, lack of access to finance is not a constraint for shelling; nor are there defaults. Another determinant of the profit is the number of hectares ploughed per season - which depends upon the frequency and lengths of tractor breakdowns. If one assumes that breakdown time and frequency can be reduced due to conditions such as better access to spare-parts and better-trained technicians (see below), the internal rate of return would increase from 27 to $35 \%$ (Scenario 2).

\footnotetext{
${ }^{3}$ [MD1-7]

${ }^{4}$ [TOW1-9, TOWA1-3, TOA1-3, UTI1-4, G4-9, IO1-5]

5 [TOW1-9, TOWA1-3] and Houssou et al. (2014a).
}

4.1.2 Public-private service providers: The agricultural mechanisation services Centres (AMSECS)

The government of Ghana promotes mechanisation based on the rationale that the drudgery of farming fosters rural-urban migration (particularly of the youth) and that banks do not finance agriculture (MoFA 2003). According to the stakeholders interviewed, mechanisation is driven by labour shortages during the ploughing and harvesting seasons and by rising farm wages. The interviewed stakeholders from the Upper West agreed that land is abundant and inexpensive. ${ }^{6}$

In the last decade, the Ministry of Food and Agriculture (MoFA) has imported approximately 3000 tractors. This figure is less than the 2000 tractors per year that the government has calculated as a target, with the aim to reduce an assumed tractor deficit of 27,133 within a decade (MoFA 2014b). The government uses loans that it receives at reduced interest rates from foreign governments to finance the tractor imports. Examples include a loan agreement of 95 million US\$ with Brazil, under which a wide range of machines and equipment was imported. Another example is a loan agreement of 5 million US\$ with Japan, under which tractors, two combine harvesters and additional equipment was purchased (MoFA 2014a).

In the beginning, tractors were provided at highly subsidised prices to individuals, but since 2007, the focus has shifted towards the AMSECs, which are run by private entrepreneurs. Officially, there are 89 AMSECs offering mechanisation services (MoFA 2014c). The plan was to set up 127 additional AMSECs by 2015 (MoFA 2010). The first AMSECs received seven tractors with implements from the government, such as disc ploughs, but AMSECs set up later received fewer pieces of equipment (e.g., only three in 2011). The AMSEC entrepreneurs had to make a down payment of 10 to $20 \%$ of the subsidised tractor package, which was offered at one-third of the actual tractor price. The AMSECs included in this study paid between 660 and 3600 US\$ depending upon the number of tractors received. ${ }^{7}$ Technically, the tractors are owned by the government until the entrepreneurs have fully paid back the tractors and equipment, which is supposed to occur within five years. AMSEC-entrepreneurs have no government restrictions concerning the prices they charge, to whom they provide service or what machinery they might choose to buy in addition to the initial package.

\subsubsection{Other types of service providers}

According to the interviews, service providers other than private owners of tractors and the AMSECs play a limited role in Ghana. This result is in line with a study by Mensah (2015), who found that only $2 \%$ of the

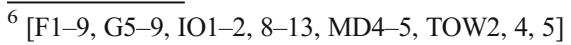

7 [AMSEC1-9, TOW3-4, G3]
} 
Table 3 Cost-Benefit Analysis of Service Provision. Remarks: Real Discount Rate: 7\%. Miscellaneous Costs include, e.g., insurance and business renewal. Operator's salary: $4 \mathrm{US} \$ / \mathrm{ha}$. The transport business is not included because it is reportedly a zero-sum game. Other farmers reported higher prices for a bag of maize shelled (up to 20 US\$). The "Improved AIS" Scenario assumes an increase of the area ploughed per year from 150 to 190 ha. According to the tractor-owner, there is sufficient unmet demand for his services and according to other stakeholder interviewed, this is a reasonable assumption once breakdown-times are reduced, for example, because the access to technicians and spare parts improves. Remarks from tractor owners located closer to urban areas having a better access to technicians and parts confirmed this assumption

\begin{tabular}{|c|c|c|c|c|}
\hline & & $\begin{array}{l}\text { Real Data: Ploughing } \\
\text { and Maize Shelling } \\
\text { Service Provision }\end{array}$ & $\begin{array}{l}\text { Scenario 1: Ploughing } \\
\text { Service Provision } \\
\text { (no maize shelling) }\end{array}$ & $\begin{array}{l}\text { Scenario 2: Ploughing } \\
\text { and Maize Shelling Service } \\
\text { Provision (improved AIS) }\end{array}$ \\
\hline \multirow[t]{8}{*}{ Annual Benefits } & Hectares ploughed per year & 150 & 150 & 190 \\
\hline & Price per ha (US\$ equivalent) & 41 & 41 & 41 \\
\hline & Default rate & $2 \%$ & $2 \%$ & $2 \%$ \\
\hline & Benefit Ploughing (US\$ equivalent) & 6.150 & 6.150 & 7.634 \\
\hline & Maize shelled (every 10th bag) & 200 & & 200 \\
\hline & Price per bag sold (US\$ equivalent) & 8.3 & & 8.3 \\
\hline & Default rate & $0 \%$ & & $0 \%$ \\
\hline & Benefit Shelling (US\$ equivalent) & 1.666 & & 1.666 \\
\hline \multirow[t]{4}{*}{ Investment Costs } & Tractor + Registration (US\$ equivalent) & 10.056 & 10.056 & 10.056 \\
\hline & Disc Plough (US\$ equivalent) & 1.000 & 1.000 & 1.000 \\
\hline & Maize Sheller (US\$ equivalent) & 533 & 0 & 533 \\
\hline & Total Investment Costs (US\$ equivalent) & 11.589 & 11.056 & 11.589 \\
\hline \multirow[t]{9}{*}{ Annual Costs } & Maintenance Cost (US\$ equivalent) & 807 & 770 & 807 \\
\hline & Fuel ploughing (3.7 gal/ha; 4 US\$ equivalent/gal) & 2.220 & 2.220 & 2.812 \\
\hline & Fuel travelling (5\% of fuel for ploughing) & 111 & 111 & 140 \\
\hline & Fuel shelling (0.1 gal/bag) & 80 & 0 & 80 \\
\hline & Total Fuel Costs (US\$ equivalent) & 2.411 & 2.331 & 3.032 \\
\hline & Miscellaneous Costs (US\$ equivalent) & 327 & 323 & 358 \\
\hline & Costs of Labour (US\$ equivalent) & 713 & 600 & 873 \\
\hline & Annual Profit (discounted) (US\$ equivalent) & 1.253 & 221 & 1.811 \\
\hline & Internal Rate of Return (annual) & $27 \%$ & $11 \%$ & $35 \%$ \\
\hline
\end{tabular}

mechanised farmers access tractors via community-based solutions such as FBOs. Even in these cases, tractors were not jointly owned. One person in the community owned the tractor, but he preferentially served other community members. The number of FBOs in Ghana is increasing, but the interviewed stakeholders had doubts that they can manage tractors because most lack both financial and management skills. Moreover, they must resolve the collective action problems discussed above. ${ }^{8}$ The interviewed financial institutions showed reluctance to finance FBOs because of a lack of fully assigned responsibilities. ${ }^{9}$

One exception is the Nso Nyame Ye Women's Group in Ejura (Ashanti), which preferentially serves small-scale and female farmers. However, the women's group was only able to overcome the financial constraints of mechanisation by becoming one of the first AMSECs.

\footnotetext{
8 [AMSEC6, IO8-9, 14, MD3-4, 6 G9, FBO1-2]

${ }^{9}$ [FI1, FI3-5]
}

According to the information collected for this study, there is no pure public sector provision of mechanisation services, such as services by district governments.

\subsection{Governance challenges within the mechanisation-AIS}

In Section 2.1., the governance challenges of mechanisation were outlined based on an empirical analysis. In this section, the governance challenges of the real Mechanisation AIS of Ghana will be presented. The terms governance challenges and "bottlenecks" will be used as substitutes. In the interviews with the respondents, the term "bottlenecks" was used because this was easier to understand. The flashes in Fig. 1 already indicated the bottlenecks. Section 4.2.1., will provide information about the relevance of these bottlenecks. The existence and degree of these challenges depends upon the types of service providers described (section 4.1.). The subsequent sections will then provide details on these bottlenecks based on our conceptual framework (the governance challenges) outlined before. 


\subsubsection{Overview of governance challenges and relevance}

To provide quantitative information on the magnitude of the different bottlenecks of the AIS, which will be analysed in more depth in the subsequent sections, Table 4 shows how many stakeholders referred to these bottlenecks during the interviews. For the purpose of this analysis, the stakeholders were divided into two categories: (1) The "frontline stakeholders", who are directly involved in the provision and use of mechanisation services. They include tractor owners and operators, farmers, spare part dealers, technicians and others (Table 2, section 3.2.). A total of 68 respondents fell into this group. (2) The second category is labelled "upstream stakeholders." They comprise the categories "government", "research and education" and "international organisations." Thirty-six respondents fell into this group. Since we did not "prompt" the respondents to comment any specific governance challenge during the interview, the number of stakeholders who identified a challenge can be seen as a quantitative indicator of the relevance that the respective stakeholder group attaches to this challenge. Table 4 also shows during how many Net-Maps session these challenges were discussed. Since the Net-Map tool is designed to systematically identify different governance challenges, one can expect that the percentage of Net-Map sessions in which a particular governance challenge is identified to be higher than that of the interviews. With the exception of soil erosion, the findings reported in Table 4 confirm this expectation. Noteworthy is that some of the bottlenecks which are seen as relevant by the "frontline" stakeholders were not mentioned by "upstream" stakeholders.

\subsubsection{Lack of training and education of farmers and tractor-technicians, operators, and owners}

Section 2.1.1 noted that the education and training of farmers, technicians, operators and owners is a merit or quasi-public good that the government must provide. The empirical evidence indicates that the Ghanaian government faces major difficulties in providing this service, although "upstream"

Table 4 Frequency of mechanisation bottlenecks as mentioned by respondents and during Net-Map sessions

\begin{tabular}{|c|c|c|c|}
\hline \multirow[t]{2}{*}{ Themes } & \multicolumn{2}{|c|}{$\%$ of respondents who mentioned theme } & \multirow{2}{*}{$\begin{array}{l}\% \text { of Net-Map sessions during } \\
\text { which the theme was mentioned ( } 8 \text { sessions }\end{array}$} \\
\hline & $\begin{array}{l}\text { Frontline stakeholders } \\
\text { (68 respondents) }\end{array}$ & $\begin{array}{l}\text { Upstream stakeholders } \\
\text { (36 respondents) }\end{array}$ & \\
\hline \multicolumn{4}{|l|}{ Knowledge and Skills } \\
\hline Limited maintenance and handling & $35 \%$ & $44 \%$ & $75 \%$ \\
\hline Limited skills of operators & $29 \%$ & $56 \%$ & $63 \%$ \\
\hline Limited skills of technicians & $26 \%$ & $22 \%$ & $63 \%$ \\
\hline \multicolumn{4}{|l|}{ Agronomics } \\
\hline Soil Erosion & $6 \%$ & $42 \%$ & $0 \%$ \\
\hline \multicolumn{4}{|l|}{ Inputs and market environment } \\
\hline Limited access to technicians & $40 \%$ & $22 \%$ & $88 \%$ \\
\hline Limited access to credit & $37 \%$ & $19 \%$ & $100 \%$ \\
\hline Sporadic fuel shortages & $29 \%$ & $0 \%$ & $25 \%$ \\
\hline Lack of market stability & $21 \%$ & $6 \%$ & $50 \%$ \\
\hline Problems with customs & $13 \%$ & $0 \%$ & $38 \%$ \\
\hline \multicolumn{4}{|l|}{ Standards and certification } \\
\hline Lack of standardized tractor/equipment-testing & $15 \%$ & $17 \%$ & $25 \%$ \\
\hline Problems with non-original spare parts & $22 \%$ & $0 \%$ & $50 \%$ \\
\hline Adulterated fuel and oil & $18 \%$ & $0 \%$ & $38 \%$ \\
\hline \multicolumn{4}{|l|}{ Small-scale and female farmers } \\
\hline Lack of access for smallholders & $40 \%$ & $36 \%$ & $100 \%$ \\
\hline Lack of access for female farmers & $13 \%$ & $33 \%$ & $38 \%$ \\
\hline \multicolumn{4}{|l|}{ Government-Imports and AMSEC } \\
\hline Lack of access to spare parts (for government-imports) & $54 \%$ & $17 \%$ & $88 \%$ \\
\hline Elite Capture and Clientelism & $22 \%$ & $47 \%$ & $75 \%$ \\
\hline Frequent Break Downs & $19 \%$ & $28 \%$ & $25 \%$ \\
\hline Low repayments & $7 \%$ & $11 \%$ & $0 \%$ \\
\hline Crowding outs effects & $9 \%$ & $0 \%$ & $13 \%$ \\
\hline Doubts of existence of AMSEC & $37 \%$ & $33 \%$ & $50 \%$ \\
\hline
\end{tabular}


stakeholders such as government-actors are well aware of these problems and although the government recently started to re-activate some old farming schools. Because the emphasis is placed on importing machinery (see above), there are only limited funds left to invest in training. Consequently, there are only erratic efforts to train tractor-operators. Interview information indicates that most tractor-operators have no specific training. The field observations conducted for this study confirmed the lack of operator skills (Schmitt 2014). Many tractoroperators do not even have a driving licence, which would only ensure driving but not operating skills. The largest public institute that offers courses for operators trained only two participants in 2012 and none in $2013 .{ }^{10}$ No public institution exists that provides training of technicians. Most technicians can be described as "roadside technicians" (see below).

Because the state provides very limited training, private training is one important aspect of the AIS. ${ }^{11}$ There are two types of private training: One is provided by international machinery companies that are active in Ghana and by their dealers. The companies and dealers train the technicians who work for them and provide tractor operator training for their customers. This opportunity, however, excludes the large market of used tractors. The second type of private training is based on an informal vocational training system ("boy/master model"). In the case of the technicians, up to 20 "boys" (apprentices) follow one workshop owner for two to three years to learn from him. Most of the owners enjoyed no formal training themselves. Some repairs are surprisingly innovative (particularly given the lack of spare-parts), but most are done on a trial and error basis and do not last long. ${ }^{12}$ This situation undermines the effective use of tractors. The problem is exacerbated because access to technicians is limited; thus, it takes days or occasionally weeks to fix even simple breakdowns. ${ }^{13}$ The problem is aggravated due to the synchronous timing of agricultural activities, which results in an accumulation of breakdowns at the beginning of the ploughing season.

The training of tractor-operators is also largely based on the "boy/master" model; "boys" are trained on the job by operators sitting on the back of the tractors. The quality of this training is mixed because "boys" often merely do simple tasks (e.g., marking tree stumps). ${ }^{14}$ As a result, ploughing is often not done to the appropriate depth, not in a straight line and without thoroughly covering weeds and turning the soil, which makes sowing difficult and increases fuel consumption. ${ }^{15}$ These

\footnotetext{
$\overline{{ }^{10}[\mathrm{G} 2-3, \mathrm{RE} 1,5]}$

11 [AMSEC1-9, TOW1-9, RE1-4, 6-7, TT1-3 UTI1-3, SPD1, MD2, 7, G1, 3]

12 [AMSEC2-3, 7, TOW1-9, RE1-4, 6-7, SPD1, MD2, 7, G1, 3, TT1-3]

13 [AMSEC1-9, TOW1-9, RE1-4, 6-7, TT1-3, UTI1-3, SPD1, MD2, 7, G1, 3]

14 [TOA1-3, TO1-2]

15 [RE1-8, G1, 3, 9, F1-9, MD2-7, IO1-3 and 10-13, UTI1-3, SPD1, AMSEC6]
}

problems do not occur only because of ignorance. Operators also face pervasive incentives because they are paid per acre ploughed and thus want to plough as much land in a given time as possible. Such incentives also draw them to plough along the slope to plough faster and to adjust their plough's diagonal to cover a larger area, which exacerbates the problems of soil erosion and degradation, which are already caused by using the disc plough under the prevailing local conditions. ${ }^{16}$

Farmers themselves have a limited understanding of the quality of ploughing services because most of them have moved directly from manual work to mechanisation (without the intermediate step of animal traction). Although farmers reported that soil erosion is a problem, few of them were concerned about it. Most suggested, "God will take care" and move to different plots if problems become severe. ${ }^{17}$ The interviewed farmers were not aware of alternatives to the disc plough such as harrows, cultivators and no-till equipment, which could reduce soil erosion and improve soil moisture management. In fact, there is little applied research on these types of farming, and applied research is not on the agenda of policymakers or extension services. ${ }^{18}$

Farmers who buy machines also find it difficult to evaluate the conditions of tractors and hence primarily choose by brand and price. ${ }^{19}$ This type of information asymmetry (section 2.1.1) benefits importers who do not overhaul the tractors they sell, allowing the tractors to be sold more cheaply because overhauls cost more than 3000 US\$. ${ }^{20}$

Information asymmetry also affects manufacturers of agroprocessing equipment. A locally produced maize sheller, which can be attached to a diesel engine or the power-takeoff of a tractor, costs less than an imported one (500 to 1600 US\$), but the quality is difficult to assess beforehand because there are neither public nor private standards or certification schemes. Many farmers thus buy foreign brands. ${ }^{21}$

\subsubsection{Disabling environment: Lack of macroeconomic stability and impeding customs practices}

An enabling environment is a public good that is crucial to all types of governance structures under which mechanisation services can be provided. The evidence collected shows that "upstream" stakeholders are largely unaware of these

\footnotetext{
$\overline{16}[\mathrm{IO1}-3,8-13, \mathrm{RE} 1-4,8, \mathrm{MD} 3,6]$.

${ }^{17}$ [F1-9, TOW2, 4-5]

18 The MoFA and the German Economic Cooperation (GIZ) among others promoted Conservation Agriculture (CA) in the early 2000s. The Soil Research Institute experiments with CA but its findings are not adhered to. However, the MoFA, which mostly imports (disc) ploughs, included some CA equipment in a recent Memorandum of Understanding with the Federal Republic of Brazil [G3, IO1-3, 8-13, RE1-4, 8, MD3, 6].

${ }^{19}$ Some tractor buyers hire technicians who help them to check the tractors [UT1-4, TOW1-2].

${ }^{20}$ [UTI1-4, TOW1-2,9]

21 [IO1-2, 5, LM1-3, G2-3, RE2]
} 
challenges that constrain the "frontline" stakeholders (Table 4, Section 4.2.1.). According to the "frontline" (and some "upstream") stakeholders, there is room for improvement in two areas: a) macroeconomic stability and b) the customs process.

a) The Mechanisation AIS of Ghana relies heavily on imports and is, therefore, susceptible to changes in the exchange rate. Providing a stable exchange rate is thus important. However, the government has not been able to achieve this goal. The Ghanaian Cedi was re-denominated and placed on parity with the US dollar in 2008 but was devaluated to 4 GHC for 1 US\$ in August 2014. This devaluation negatively affected the emerging private importers of new and used tractors. According to interview information, imports came to a halt in 2013 and $2014 .^{22}$ The devaluation of the GHC also affected the importers of spare-parts. Owners of tractors had to continue to buy spare-parts, but they switched to non-original parts and purchased fewer wearing parts - a coping mechanism that increases the likelihood of future breakdowns. ${ }^{23}$

b) The import of agricultural machinery, equipment and spare-parts is exempted from import taxes. However, importers of new and used tractors and spare-part dealers reported that the application process for exemption is tedious and involves corruption, a typical governance problem of public service provision (section 2.1.2). According to the interviewees, paying no bribes delays the approval process and increases the likelihood of partial tax exemptions, which can be applied when goods can also be used in non-tax-exempted areas. For example, spare parts that can be used for both tractors and cars. Consequently, importers reported refraining from applying for exemptions for urgently needed parts. ${ }^{24}$ In general, even without applying for tax exemptions, the customs process was reported to be slow. ${ }^{25}$

In contrast to imported agricultural goods, stainless steel (needed to manufacture, e.g., maize shellers) is charged an import duty of 10-20\% and a VAT of $12.5 \%$, which is a disadvantage for local manufacturers. These manufacturers also struggle with other obstacles, including an erratic electricity supply and limited access to credit, training and materials. ${ }^{26}$

\subsubsection{Marginalisation of small-scale and female farmers}

Section 2.1.1 noted that a non-clearing market can lead to exclusion, particularly of groups that have low bargaining power and confront high transaction costs. The empirical

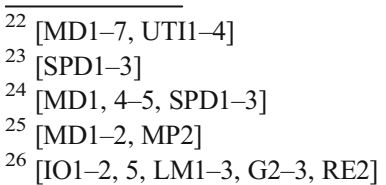

23 [SPD1-3]

${ }^{24}$ [MD1, 4-5, SPD1-3]

26 [IO1-2, 5, LM1-3, G2-3, RE2]

study found that, indeed, both private service providers and the public-private AMSECs are reluctant to serve smallholders. As land size is a crucial determinant here, we follow the definition of smallholders as used by the Ghanian Ministry of Agriculture and Food (MOFA 2013) and define smallholders as farmers who own less than 2 ha. Per definition, the fields of smallholders are small and they may also be spatially dispersed. Smallholder fields are also more likely to have stumps and stones. According to the providers, there is sufficient unmet demand from farmers with larger landholdings, and servicing them involves lower transaction costs. ${ }^{27}$ Smallholders who have their fields ploughed too late are not able to sow and risk a sharp drop in yield. According to Sallah et al. (1997), a 14-days delay results in maize yield losses up to $30 \%$ in the Guinea Savanna.

Smallholders must also accept low quality ploughing because their bargaining power is weak and because they do not have a favourable fall-back position. Farmers, development practitioners and researchers reported that operators regularly take advantage of the unequal power balance and leave before the acreage to be ploughed has actually been completed. Female farmers are especially marginalised because they typically own rather small plots of low quality land. The fact that tractor-owners and operators are mostly male causes additional problems of access for female farmers. ${ }^{28}$ The empirical study indicated that in some instances, smallholder farmers form groups and address service providers jointly, which reduces transaction costs and increases the farmers' bargaining power, in turn improving their access to rental markets.

\subsubsection{Poor access to rural finance}

Market failure in agricultural finance was identified as a major constraint to mechanisation that affects both investments in tractors and the financing of tractor services (Section 2.1.1). The study indicated that, as expected, loans by private banks are difficult to obtain. Farmers and owners of tractors reported that the application for a loan from a private bank is tedious and that the repayment schedule is stringent and not adapted to the characteristics of farming. Loans must be paid back continuously and within a period of 12 (rarely 24) months, although tractors must be operated for longer periods before the investment is recovered. Banks have interest rates of up to $35 \%$ per year (plus charges) because of high transaction costs, high inflation and high default rates. ${ }^{29}$

Bank representatives explained that they find it difficult to lend to farmers without land titles or any other collateral. Some banks allow the tractor to be financed with collateral (with a down payment of $30 \%$ ) and register it under joint ownership

\footnotetext{
$\overline{27}$ [AMSEC1-9, TOW1-9, F1-9, IO1-3, 10-13, RE1-4, 8]

${ }^{28}$ [F1-9, IO1-3, 10-13, RE1-4, 8]

29 [TOW1-9, F1-9, FI1-4, MD3, 5-6]
} 
until the credit is repaid. This goes beyond the "strong ownership" suggested by Binswanger (1986) that increases the ease of use of a "mobile, fragile and indivisible" factor as collateral but requires enforceable property rights. The World Economic Forum (Schwab and Sala i Martin 2014) rates the property right enforcement in Ghana with 4.2 on a range from 1 (poorly defined/not protected) to 7 (well defined/protected). However, few instances of such an arrangement could be found. ${ }^{30}$

Given the difficult access to loans by private banks, most tractors were reportedly financed with personal savings and loans given by friends and relatives who work outside agriculture.

Farmers who want to receive tractor services face equal problems of access to finance. They try to negotiate in-kind payments and to borrow from relatives, moneylenders and traders. These informal private financial channels involve high interest rates (up to $150 \%$ per year), but lending involves no cumbersome procedures and repayment is more flexible. There are examples of group-based microfinance institutions supported by NGOs, but in general, the findings indicate that microfinance is not common in rural farming areas. Even when it is available, it is not suitable to finance (used) tractors. ${ }^{31}$

One interesting example in which private and third sector institutions cooperate to address the market failure of agricultural finance is a loan guarantee scheme run by the Danish International Development Agency (DANIDA) in cooperation with three banks. DANIDA covers half of the default risk, which allows the banks to reduce their interest rates. Some tractor dealers reduce the interest rate even further when the tractors to be financed are of their brand. Loans under this DANIDA-supported scheme are given only to farmers who provide tractor services to smallholder farmers. ${ }^{32}$

\subsubsection{Mixed access to spare-parts and fuel}

The evidence collected in this study shows that there is a sharp divide in the access to spare-parts for tractors that are imported by private entities and those imported by the state. The access to spare-parts of brands which have been used in Ghana for decades, such as Massey Ferguson and Ford, is generally good, which can be viewed as a consequence of path dependency. These brands have sufficiently large tractors to create incentives for private investments into the spare-parts business. In contrast, the number of tractors of the different brands that were imported recently by the state is too low to make private investments into spare-parts for those brands profitable. Consequently, access to spare-parts is insufficient. ${ }^{33}$ Table 4 has shown that "upstream" stakeholders largely underestimate this

${ }^{30}$ [FI1-5]

31 [TOW1-9, F1-9]

32 [IO7, MD7, FI5]

33 [RE1-2, AMSEC1-9, TOW1-9, TOWA1-3, TOAD2, TT1-4, UTI1-4, SPD1-3, G1, 3, 9, IO5, MD2-3, 5-6] problem although it contributes to frequent and lasting breakdowns for government-imported tractors (section 4.2.8).

The number of tractors of these brands is low because the government financed those imports with concessional loans that were linked to the obligation to purchase particular brands manufactured in the country providing the loan (section 4.2.8). For example, there are 232 Mahindra, 78 Kubota and 40 Landini tractors in the country (MoFA 2014b). There are more Farmtrac tractors (1306), but the threshold making private investments in spare-parts reasonable was still not reached, partly because many of those tractors are already out of operation. As a result, a large market for cheap nonoriginal parts has emerged. Such parts are of low quality and contribute to frequent breakdowns. ${ }^{34}$

The situation is different for new tractors that are imported by the dealers of large machinery companies. In these cases, access to spare-parts is usually good, but these parts are very expensive because the dealers of new tractors struggle to reach economies of scale and primarily sell to large commercial farms. ${ }^{35}$ The access to spare-parts of privately imported tractors that do not belong to the major brands is not necessarily good either. Some stakeholders reported that there are importers of tractors from, e.g., China who quickly sell tractors but have no intention of providing any after-sales services. ${ }^{36}$

In addition to spare-parts, access to fuel and oil is a crucial aspect of mechanised farming systems. Tractor-owners reported that access to fuel and oil improved in recent years, but that access can be unreliable in remote towns. Moreover, countrywide fuel shortages occur sporadically, which can have severe effects during the ploughing season. ${ }^{37}$ For example, in July 2014, because of not settling its debts with international suppliers, no fuel was released to Ghana for several weeks. Tractor-owners also reported that adulterated fuel and oil (mixed with kerosene) is a problem. Such adulteration is difficult to detect beforehand and is a problem of information asymmetry and lack of government regulation (section 2.1). Low fuel and oil quality has negative effects on engines, catalysts and fuel injectors, resulting in a high number of broken fuel and hydraulic pumps. ${ }^{38}$

\subsubsection{Tractor operator-owner relationship and maintenance}

Tractor-operators frequently work in remote areas in which they are hired by customers in one-off deals. They are usually not supervised by the tractor-owners because doing so is

\footnotetext{
${ }^{34}$ Owners also reported to weigh the risk that a generic part causes a breakdown in the future against the benefits of spending less now [TOW1-9, AMSEC1, 3, SPD1-3, MD1]

35 [MP1, MD1-7].

${ }^{36}$ [IO4, SPD3, G9]

37 [AMSEC3, IO1, TOW1-9, TOWA1-4, TO1-2, TOA1-3]

38 [TT1-4, SPD1-3]
} 
associated with high transaction costs; the lack of supervision leads to principle-agent problems (section 2.1.1). ${ }^{39}$ Operators have few incentives to ensure proper maintenance because costs of breakdowns are not borne by them and because they are paid per acre ploughed. Hence, spending time on maintenance is income forgone for them. Breakdowns are also income forgone for the operators, depending upon their opportunity costs, but whereas ignoring maintenance increases income in the short term, following maintenance rules ensures income in the long term, a problem caused by high time-discount rates.

The same logic provides incentives for operators to plough quickly and ignore obstacles such as stumps and stones because the damages and increased fuel costs are not borne by the operators. ${ }^{40}$

Furthermore, tractor-owners themselves have an incentive to have as much land ploughed as possible in a given time because they might also have a high time-discount rate. This problem was confirmed by spare-parts dealers, who noted that owners rarely buy wearing parts such as filters. ${ }^{41}$

The interviews indicate that there are, of course, also tractor-owners who acknowledge the importance of maintenance. However, this understanding does not guarantee good maintenance because many lack the necessary knowledge. For example, dust frequently enters machines during oil changes. ${ }^{42}$ The use of tractor-operators also leads to payment problems; tractor-owners and development practitioners, among others, reported that operators commonly 'line their own pockets.' Taking advantage of information asymmetry, they do so by underreporting the acreage they plough. ${ }^{43}$

\subsubsection{Challenges with government imports and the AMSECs}

In Section 2.1.2, several reasons for potential state failures were identified. The empirical evidence collected for this paper indicates that these challenges indeed affect the imports of tractors by the government and the AMSECs, the publicprivate partnership mechanisation model pursued in Ghana. Most of the governance challenges arise from the missing link between demand and supply. As mentioned above, the imports of tractors are financed through concessional loan agreements with emerging countries such as Brazil and India, and through grants by developed countries such as Japan. Under these arrangements, the Government of Ghana had to choose tractors to be imported from a list of pre-selected producers, typically from the lending country. This arrangement can preclude the selection of the most suitable brands and hinders private investments in spare-parts (section 4.2.5). In contrast, farmers or other entrepreneurs who select tractors themselves

\footnotetext{
39 [SPD1-3, RE1-2, G3, 9, TT1-4, MD1-7, IO1-2]

40 [MD2-7, UTI1, SPD1, G9, IO1-2]

41 [AMSEC1, 3, RE1-2, MD1-3, SPD1-3, TOWA1-3, TOW1-9]

42 [AMSEC2, TT1-2, MP2]

43 [IO1-2, MD2, G3, AMSEC2-4, UTI2-3, TOW2, 4, 8]
}

include the accessibility to and affordability of spare-parts in their decision-making and almost exclusively purchase Massey Ferguson and Ford tractors.

The entrepreneurs who run the AMSECs received government-imported tractors and therefore did not have this choice. Difficult access to spare-parts, combined with a lack of appropriate maintenance and the absence of qualified operators and technicians, have resulted in frequent and long breakdowns, which are reflected in the sharp decline in the acreage ploughed by the AMSECs per year observed in recent years. ${ }^{44}$ An example is one AMSEC in the study region that initially, in 2009, ploughed 140 ha with each of its three tractors but ploughed only 40 ha in 2014. Another AMSEC ploughed 200 ha with nine tractors in its first year, 2008, but ploughed only 40 ha with the only two tractors that remained functioning in 2014. ${ }^{45}$ Some interviewed operators of AMSECs reported that they concentrate their efforts on the most "promising" tractors received. The following figures illustrate this problem: the nine interviewed AMSEC-operators owned together 14 Farmtrac-tractors, but only five of them were in operation at the time of this study. ${ }^{46}$ In general, a substantial number of the government-imported tractors were reported broken down and "cannibalised" to provide spare-parts to other broken-down tractors from the same brand. Of 500 John Deere tractors imported by the government in 2008, only 200 remained in operation in 2014. ${ }^{47}$

The problem of breakdowns, which is likely to increase with the age of tractors, led to a low repayment for the subsidised AMSEC tractors. ${ }^{48}$ Repayment capacities may also be linked to different socioeconomic, agronomic and institutional conditions (e.g. the number of small farms, the proximity to spare part hubs and technicians) and management capabilities. However, government officials also suggested that some AMSEC operators believe that they are entitled to "a part of the national cake" and "play games" because some AMSECs would actually be able to repay their loans. Some bought additional equipment outside the government credit facility. ${ }^{49}$ Theoretically, the repayment is tightly regulated (including the option for repossession), but - in line with the considerations of the financial sustainability of government schemes outlined in Section 2.1.2 - such rules are not strongly enforced. ${ }^{50}$ The low repayment is a burden for the government budget. Moreover, the plan to have a revolving fund, in which repayments are used to buy additional tractors, cannot be implemented. Currently, the MoFA experiments with higher down payments combined with higher subsidies and plans to

\footnotetext{
$\overline{44 \text { [AMSEC1-9] }}$

45 [AMSEC4,6]

46 [AMSEC1-9, G3-4, 6-9, RE1-2, 10, 7, TOWA1]

${ }^{47}$ [AMSEC1-2, 4, 7, TOW3-4, MD4]

48 [AMSEC1-3, 7-8, G1, 3, IO4-5]

49 [G1, 3, IO4]

50 [AMSEC1-2, 4, G1, 3]
} 
use banks (with the reputation and capacities to track defaulters) as intermediates.

A second set of governance challenges arises from political interest and elite capture (section 2.1.2.). Beneficiaries of and applicants for government tractors that were imported before the government shifted its focus towards the AMSECs stated that tractors were typically used to reward party members, friends and voters, or were "captured" by politicians. ${ }^{51}$ Anecdotal evidence also suggests that 50 Mahindra tractors were smuggled to Burkina Faso, which has a high import tax on agricultural machinery (WTO 2014). ${ }^{52}$ Similar problems appear to affect the AMSEC programme. Interviewees noted that designated AMSEC tractors were used as giveaways and that some were taken by politicians. ${ }^{53}$ In one region, designated AMSEC tractors were given to the local District Assemblies (i.e., the district administration in Ghana) to set up the AMSECs because there no qualified entrepreneurs could be identified. On paper, this approach worked; official documents list nine such AMSECs. In reality, it did not work. Observations and reports from key informants suggest that the District Assemblies received the tractors, but few set up the AMSECs. ${ }^{54}$ This omission might explain why several respondents from different regions in Ghana even questioned the existence of the AMSECs. ${ }^{55}$ Some of the interviewed AMSEC owners explained that they use the subsidised tractors primarily to plough their own fields.

One governance challenge raised in the theoretical part was the crowding out of private actors (section 2.1.2.). The empirical evidence collected for this study provides a mixed picture. Some importers of tractors stated that it is difficult to compete with the subsidised imports, whereas others did not. ${ }^{56}$ The evidence on whether the AMSECs crowd out private service providers does not provide a clear picture either because in the main study area (the Upper West), few AMSECs were actually in operation. In the Volta region, private service providers reported competing with AMSECs but that much unmet demand remains. Some service providers also reported that the initial competition ceased as AMSECs faced problems with breakdowns. ${ }^{57}$

\section{Discussion}

The appropriate role of the state in promoting agricultural development remains heavily debated both in the academic literature and in policy. In a study of policy processes in Ghana, Uganda and Senegal, Mockshell and Birner (2015)

\footnotetext{
${ }^{51}$ [AMSEC4, 6, 7, G5-9, IO8-9, MD2, 4, 7, RE10, UTI2-3, TOW4]

52 [MD2-3, 6, IO8-9]

53 [AMSEC1, 3-5, G1-7, RE1-2, 10, IO8-9, MD2, 7, TOWA1, UT12-3]

54 [G3-4, 6-9, TOWA1]

55 [RE1-4, 10, UTI1, G4-6, 8-9, MD3, 5-6, F1-9, TOW1-9, IO8-9]

56 [MD1-7]

57 [TOW8-9]
}

found that domestic policymakers and donors in Ghana typically have different views on this point. Domestic policymakers tended to favour a strong role of the state, whereas development partners favoured market-led strategies. Domestic policymakers also placed more emphasis on mechanisation, highlighting the need to overcome the prevailing "hoe and cutlass" type of farming to make agriculture attractive to the youth. These policy beliefs might explain the focus of the MoFA on the supply of subsidised tractors to individuals and the AMSECs, despite the "miserable track record" of past state-led mechanisation (FAO 2015, para. 2).

This intended supply push for technology by the state addresses the capital problems of mechanisation. The push might have had an initial impetus on mechanisation, as shown in a study by Benin (2015), who found that the AMSEC program contributed to improving the availability of mechanisation services. However, the evidence collected for this study shows that the well-known governance challenges inherent to such a mechanisation strategy are difficult to resolve - even for a country such as Ghana, which has respectable governance indicators (World Bank 2013). The frequent breakdowns of tractors and the sharply dropping acreage ploughed in recent years observed by the interviewed AMSECs suggest that the initial impetus of this mechanisation strategy might not be lasting (section 4.2.8). The data used in the study by Benin are from 2011, when most AMSEC tractors were relatively new (the first AMSECs were set up in 2008; the latest were set up in 2011). Hence, the data do not capture the effects of missing spare-parts, omitted maintenance and the subsequent decline of acreage ploughed in recent years.

This observation resembles the failures of past state-led mechanisation. According to Mrema et al. (2008, p.25), one lesson from these failures is that policymakers should not attempt to "accelerate short-term technology transfer rates through direct (...) machinery supply and services". The MoFA in Ghana followed this appeal partly by promoting services provision not directly but indirectly via the AMSECs, which are run by private entrepreneurs. This strategy was supposed to address the managerial and incentive problems inherent in past mechanisation schemes. However, AMSEC entrepreneurs have still been selected by the state, and the centres were equipped with tractors chosen and imported by the state. The evidence collected suggests that this approach involves governance problems that affect the economic viability of the AMSECs (see also Diao et al. 2014). As indicated above, e.g., access to spare-parts for the selected brands is limited (section 4.2.6 and 4.2.8). Moreover, the AMSEC approach - with its emphasis on importing machinery - did not entail sufficient investment in the generation of needed knowledge and skills in tractor-operators, technicians and farmers, which would be required for a successful mechanisation strategy. The absence of knowledge and 
skills development results among other factors in frequent and long-lasting breakdowns. This is in line with Houssou et al. (2014a) who analysed the operations of 136 Ghanaian tractor-service-providers and found that $86 \%$ of them were not able to use their tractors during the entire cultivation period because of breakdowns. These findings create doubts concerning whether the government's strategy is the most effective pathway towards mechanisation that is sustainable from an economic, social and environmental perspective.

The AIS approach applied in this study indicates that a range of other bottlenecks in the innovation system also affects mechanisation in Ghana - apart from the absence of education and training for technicians and operators that reduces the profitability of tractors and affects both AMSECs and private service providers (section 4.1.1.). As the study showed, "frontline" stakeholders and especially the emerging private import and service markets are also influenced by a lack of access to agricultural finance, impeding customs practices and exchange rate fluctuations (Table 4, Section 4.2.3. and 4.2.5.).

While the state focuses on imports of tractors and the AMSECs, these institutional bottlenecks have received limited attention by policymakers. This is striking because "upstream" stakeholders such as policymakers seem to be well aware of the governance challenges of such an approach (section 4.2.1.) and as it is well-known from the literature that technology-driven productivity growth cannot be sustained without enabling institutions (Hounkonnou et al. 2012). Potentially, these bottlenecks receive little attention because investing in institutions is politically less attractive than importing tractors (Birner and Resnick 2010). The evidence collected here, by Diao et al. (2012) and especially Benin (2015) on clientelism and political targeting confirm this.

Considering that all types of governance structures (state, market and communities) have their own challenges but also their unique advantages, a combination of public, private and third sector institutions such as farmer based organizations or development organisation appears most promising to create an enabling institutional environment. In the light that policymakers are largely unaware of many "frontline"mechanisation bottlenecks (section 4.2.1.), such a combination can also help to create the appropriate "checks and balances" for mechanisation. The institutional setting in countries that have successfully mechanised their agriculture supports this proposition. In Germany, for example, the training of operators was initially offered by public schools (Deutsche Landkraftführerschule), which became an association (third sector) later. Tractor-evaluations are done and published by an independent association (Deutsche Landwirtschafts-Gesellschaft), which also organises machinery exhibitions and publishes books. The training of operators and mechanics could be provided by the private and third sectors, with quality assurance by the government, and could combine the advantages of formal and informal hands-on, on-the-job training. Another example of how actors from different sectors can cooperate is the loan guarantee scheme initiated by DANIDA (section 4.2.5). Bearing in mind the soil erosion problems, such schemes could also focus on non-till machinery. One distinctive advantage of the DANIDA scheme is that farmers themselves decide which machinery they want to buy, considering quality, size, price and after-sales services.

\section{Conclusions}

This study showed that all types of governance structures under which mechanisation services can be provided - market, state and community - face governance challenges. Many of these governance challenges have been neglected - both in practice and in the research-based literature on mechanisation - despite the overwhelming evidence that neglecting governance challenges has contributed to the failure of past mechanisation approaches. This paper has combined the concept of governance challenges with the Agricultural Innovation Systems concept to draw attention to these crucial bottlenecks. Both the theoretical approach and the empirical findings of this paper can be relevant not only for Ghana but also for the large set of African countries that currently aim to promote mechanisation. Moreover, the findings should stimulate more research to "quantify" the implications of the identified neglected governance challenges. For example, it would be interesting to quantify the effects of limited knowledge and skills development of operators and technicians not only on individual service providers but also on the complete agricultural sector and the rate of return for government spending on mechanisation.

Clearly tough, the findings indicate that governments must focus on the entire Agricultural Innovation System to make mechanisation sustainable from an economic, social and environmental perspective. Instead of focusing only on the supply of subsidised machinery, governments could be more effective by supporting a conducive institutional environment for the emerging used-tractor and service markets. Such support would include strengthening the capacity of the education and training domain in the innovation system, improving the customs process, maintaining market stability, and investing in applied research on sustainable types of mechanisation. Considering the soil erosion problems of (disc-)ploughing, such research might well include a focus on mechanised Conservation Agriculture. Finally, the study suggests that a combination of public, private and third sector institutions are needed to create the "checks and balances" that are required for an enabling institutional environment for mechanisation. 
Acknowledgements The authors would like to express their gratitude to all persons who took part in the interviews and Net-Map exercises. We would like to express our special gratitude to Felix Asante, Antony Chapoto, Nazaire Houssou and Shashidhara Kolavalli for their support during the field research. We would also like to thank Karlheinz Köller, Lisa Jäckering, Esther Mensah, Juliet Kariuki, Jonathan Mockshell, Miriam Romero and Florian Schmitt for their valuable comments. We gratefully acknowledge the financial support of Deere \& Company for the fieldwork. We are also grateful for the financial support from the "Program of Accompanying Research for Agricultural Innovation" (PARI), which is funded by the German Federal Ministry of Economic Cooperation and Development (BMZ).

\section{Compliance with ethical standards}

Funding The Deere \& Company funded the fieldwork for this study. While writing this paper, Thomas Daum has received financial support from the "Program of Accompanying Research for Agricultural Innovation" (PARI), which is funded by the German Federal Ministry of Economic Cooperation and Development (BMZ).

Conflict of interest The Deere \& Company funded the fieldwork for this study.

Open Access This article is distributed under the terms of the Creative Commons Attribution 4.0 International License (http:// creativecommons.org/licenses/by/4.0/), which permits unrestricted use, distribution, and reproduction in any medium, provided you give appropriate credit to the original author(s) and the source, provide a link to the Creative Commons license, and indicate if changes were made.

\section{References}

Adesina, A. (2013). Low level of mechanisation limits ability of farmers, Discourages Youth In Agriculture. Speech of the Minister of Agriculture and Rural Development Nigeria. www.fmard.gov.ng/ news_inside/19. Accessed 21 July 2015.

Adjei, E., Aikins, S., Boahen, P., Chand K., Dev, I., Lu, M., Mkrtumyan, V., Samaraweera, S., Teklu, A. (2003). Combining mechanisation with conservation agriculture in the Brong Ahafo region, Ghana. ICRA Working Series 108

Akerlof, G. (1970). The market for "lemons": Quality uncertainty and the market mechanism. The Quarterly Journal of Economics. https:// doi.org/10.2307/1879431.

Ashburner, J., \& Kienzle, J. (2011). Investment in Agricultural Mechanisation in Africa: Conclusions and recommendations of a round table meeting of experts. Agricultural and Food Engineering Technical Reports, 8 (FAO).

Banerjee, A., \& Duflo, E. (2011). Poor economics: A radical rethinking of the way to fight global poverty. New York: Public Affairs.

Bator, F. M. (1958). The anatomy of market failure. The Quarterly Journal of Economics, 72(3), 351-379.

Baumhardt, R. L. (2003). Dust Bowl Era. Encyclpedia of Water Science. https://doi.org/10.1201/NOE0849396274.ch61.

Benin, S. (2015). Impact of Ghana's agricultural mechanization services center program. Agricultural Economics. https://doi.org/10.1111/ agec. 12201

Benin, S., Johnson, M., Jimah, K., Taabazuing, J., Tenga, A., Abokyi, E., ... Owusu, V. (2013). Revisiting agricultural input and farm support subsidies in Africa: The case of Ghanas mechanisation, fertilizer, block farms, and marketing programs. IFPRI Discussion paper 1300. https://doi.org/10.2139/ssrn.2373185.

Binswanger, H. (1986). Agricultural mechanisation: A comparative historical perspective. World Bank Research Observer. https://doi.org/ 10.1093/wbro/1.1.27.

Binswanger, H., \& McIntire, J. (1987). Behavioral and material determinants of production relations in land-abundant tropical agriculture. Journal of Economical Development and Cultural Change. https:// doi.org/10.1086/451637.

Birner, R., \& Anderson, J. (2007). How to make agricultural extension demand-driven? The case of India's agricultural extension policy. IFPRI Discussion Paper 00729. Washington, DC: International Food Policy Research Institute.

Birner, R., \& Resnick, D. (2010). The political economy of policies for smallholder agriculture. World Development. https://doi.org/10. 1016/j.worlddev.2010.06.001.

Bitsch, V. (2005). Qualitative research: A grounded theory example and evaluation criteria. Journal of Agribusiness, 23(1), 75-91.

Bowles, S., \& Gintis, H. (1993). The revenge of homo Economicus: Contested Exchange and the Revival of Political Economy. Journal of Economic Perspectives. https://doi.org/10.1257/jep.7.1. 83.

CEPS (Customs; excise and preventive services division Ghana). (2012). Import data.

Chapoto, A., Houssou, N., Mabiso, A., \& Cossar, F. (2014). Medium and large-scale farmers and agricultural mechanization in Ghana: Survey results. Ghana Strategy Support Program. IFPRI.

Clark, N., Hall, A., Sulaiman, R., \& Naik, G. (2003). Research as capacity Building: The Case of an NGO Facilitated Post-Harvest Innovation System for the Himalayan Hills. World Development. https://doi. org/10.1016/j.worlddev.2003.04.001.

Deininger, K. W., \& Byerlee, D. (2011). Rising global interest in farmland: Can it yield sustainable and equitable benefits? Washington: World Bank Publications.

Diao, X., Cossar, F., Houssou, N., Kolavalli, S., Jimah, K., \& Aboagye, P. (2012). Mechanisation in Ghana: Searching for sustainable service supply models. IFPRI Discussion Paper 01237.

Diao, X., Cossar, F., Houssou, N., \& Kolavalli, S. (2014). Mechanisation in Ghana: Emerging demand and the search for alternative supply models. Food Policy. https://doi.org/10.1016/j.foodpol.2014.05. 013.

Diao, X., Silver, J., \& Takeshima, H. (2016). Agricultural mechanization and agricultural transformation (Vol. 1527). IFPRI Discussion Paper 01527.

Ekboir, J., \& Parellada, G. (2002). Public-private interactions and technology policy in innovation processes for zero tillage in Argentina. Agricultural research policy in an era of privatization, 137-154.

Douglas, K. (2014). John Deere on the trends driving African farming. How we made it in Africa. www.howwemadeitinafrica.com/johndeere-on-the-trends-driving-african-farming. Accessed 23 June 2014

Fafchamps, M. (2001). Networks, Communities and Markets in SubSaharan Africa: Implications for Firm Growth and Investment. Journal of African Economics. https://doi.org/10.1093/jae/10. Suppl2.109.

FAO (2015). Agricultural mechanisation strategy. Rural Infrastructure and Agro-Industries Division. www.fao.org/ag/ags/agriculturalmechanisation/agricultural-mechanisation-strategy-ams/en/. Accessed 15 Dec 2015.

Feder, G., Just, R., \& Zilberman, D. (1985). Adoption of agricultural innovations in developing countries: A survey. Economic Development and Cultural Change, 33, 255-298.

Hounkonnou, D., Kossou, D., Kuyper, T.W., Leeuwis, C., Nederlof, E.S., Röling, N., Sakyi-Dawson, O., Traoré, M., van Huis, A. (2012) An innovation systems approach to institutional change: Smallholder development in West Africa. Agricultural Systems 108:74-83 
Houssou, N. \& Kolavalli, S. (2013): Animal traction in Ghana. IFPRI Ghana Strategy Support Program Discussion Note 28.

Houssou, N., Diao, X., \& Kolavalli, S. (2014a). Economics of tractorowners hip under rainfed agriculture with applications in Ghana. IFPRI Discussion Paper 01387.

Houssou, N., Diao, X., \& Kolavalli, S. (2014b). Can the private sector lead agricultural mechanisation in Ghana? IFPRI Ghana Strategy Support Program Policy Note 4.

Ilukor, J., Birner, R., Rwamigisa, P. B., \& Nantima, N. (2015). The provision of veterinary services: Who are the influential actors and what are the governance challenges? A case study of Uganda. Experimental Agriculture. https://doi.org/10.1017/ S0014479714000398.

Jayne, T. S., Chamberlin, J., \& Headey, D. D. (2014a). Land pressures, the evolution of farming systems, and development strategies in Africa: A synthesis. Food Policy. https://doi.org/10.1016/j.foodpol. 2014.05.014.

Jayne, T.S., Chapoto, A., Sitko, N., Nkonde, C., Muyanga, M., Chamberlin, J. (2014b). Is the scramble for land in Africa foreclosing a smallholder agricultural expansion strategy? Journal of International Affairs, 67(2), 35.

Kherallah, M., \& Kirsten, J. (2001). The new institutional economics: Applications for agricultural policy research in developing countries. IFPRI Discussion Paper 41.

Kydd, J., \& Dorward, A. (2004). Implications of market and coordination failures for rural development in least developed countries. Journal of International Development. https://doi.org/10.1002/jid.1157.

Mensah, E. (2015). Assessment of farm household choices regarding the demand for agricultural mechanization. Master Thesis. University of Hohenheim.

Mockshell, J., \& Birner, R. (2015). Donors and domestic policy makers: Two worlds in agricultural policy-making? Food Policy. https://doi. org/10.1016/j.foodpol.2015.05.004

MoFA (2003). Establishment of agricultural mechanisation services and support centres in Ghana. Internal Paper. Agriculture Engineering Services Division.

MoFA (2010). Medium Term Agricultural Sector Investment Plan: 20112015. http://agricinghana.com/wp-content/uploads/2013/02/ medium-term-agriculture-sector-investment-plan-ghana.pdf. Accessed 09 August 2017.

MoFA (2013). Agriculture in Ghana: Facts and figures. Statistics, Research and Information Directorate. http://agrihomegh.com/wpcontent/uploads/2017/01/Mofafactsandfigures2012.pdf. Accessed 09 August 2017.

MoFA (2014a). Data and calculations on government imported machinery. Agriculture Engineering Services Division.

MoFA (2014b). List of AMSEC. http://mofa.gov.gh/site/?page $\mathrm{id}=$ 10235. Accessed 10 June 2016.

MoFA (Ministry of Food and Agriculture). (2014c). Achievements. http://mofa.gov.gh/site/?page id=3937. Accessed 13 July 2015.

Mrema, G. C., Baker, D., \& Kahan, D. (2008). Agricultural mechanisation in sub-Saharan Africa: Time for a new look. Agricultural Management, Marketing and Finance Occasional Paper, 22 (FAO)

Musgrave, R. (1959). The theory of public finance. New York, McGrawHill
Nin-Pratt, A., \& McBride, L. (2014). Agricultural intensification in Ghana: Evaluating the optimist's case for a Green Revolution. Food Policy. https://doi.org/10.1016/j.foodpol.2014.05.004.

Olmstead, A. L., \& Rhode, P. W. (1995). Beyond the threshold : An analysis of the characteristics and behavior of early reaper adopters. The Journal of Economic History. https://doi.org/10.1017/ S0022050700040560.

Ostrom, E. (1990). Governing the commons: The evolution of institutions for collective action. Cambridge: Cambridge University Press.

Pingali, P. (2007). Agricultural mechanisation: Adoption patterns and economic impact. Handbook of Agricultural Economics. https:// doi.org/10.1016/S1574-0072(06)03054-4.

Pingali, P., Bigot, Y., \& Binswanger, H. P. (1987). Agricultural mechanisation and the evolution of farming systems in subSaharan Africa. American Journal of Agricultural Economics, 70(2), 498

Raabe, K., Birner, R., Sekher, M., Gayathridevi, K. G., Shilpi, A., \& Schiffer, E. (2010). How to overcome the governance challenges of implementing NREGA. IFPRI Discussion Paper 00963.

Sacerdoti, E. (2005). Access to Bank credit in sub-Saharan Africa - key issues and reform strategies. IMF Working Paper 05/166. https://doi. org/10.5089/9781451861853.001.

Sallah, P., Twumasi-Afriyie, S. and Kasei, N. (1997). Optimum planting dates for four maturity groups of maize varieties grown in the Guinea savanna zone. Ghana Journal of Agricultural Science 30: 63-69.

Schiffer, E. (2007). Influence mapping of social networks. Sunbelt conference, Corfu, Greece (01 - 06 may 2007).

Schmitt, F. (2014). Assessment of current mechanization strategy for smallholder farmers in Ghana and options for improvement Master Thesis. University of Hohenheim.

Schwab, K., Sala i Martin, X. (2014).The Global Competitiveness Report 2013-2014. Geneva: World Economic Forum.

Spielman, D., \& Birner, R. (2008). How innovative is your agriculture ? Using innovation indicators and benchmarks to strengthen National Agricultural Innovation Systems. The World Bank Agriculture and Rural Development Discussion Paper 41.

Starkey, P. H. (2000). Empowering farmers with animal traction: Worldwide trends, issues and challenges. In P. Kaumbutho, R. Pearson, \& T. Simalenga (Eds.), proceedings of the workshop of ATNESA (Vol. 20). Mpumalanga, South Africa.

Sunding, D., \& Zilberman, D. (2001). The agricultural innovation process: Research and technology adoption in a changing agricultural sector. Handbook of Agricultural Economics, 1, 207-261.

Takeshima, H., Nin Pratt, A., \& Diao, X. (2013). Agricultural mechanisation patterns in Nigeria: Insights from farm household typology and agricultural household model simulation. IFPRI Discussion Paper 01291.

USAID. (2013). Country profile Ghana: Property rights and resource governance. DC: Washington.

World Bank. (2006). Enhancing agricultural innovation: How to go beyond the strengthening of research systems. Washington DC: World Bank. https://openknowledge.worldbank.org/handle/10986/7184. Accessed 09 August 2017.

World Bank (2013). Worldwide Governance Indicators. http://info. worldbank.org/governance/wgi/\#home. Accessed 18 July 2017.

WTO (2014). Trade policy review - Burkina Faso. Report by the Secretariat. 


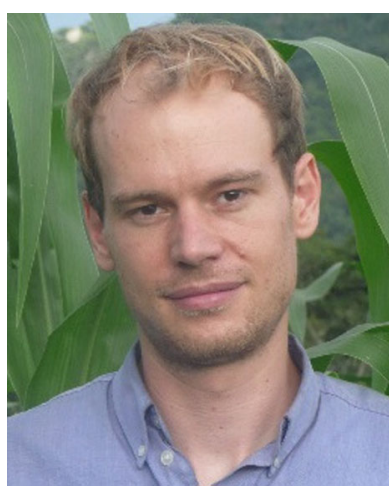

Thomas Daum is a doctoral candidate at the Institute of Agricultural Science in the Tropics (Hans-RuthenbergInstitute). His $\mathrm{PhD}$ is part of the Program of Accompanying Research for Agricultural Innovation (PARI), which aims to contribute to sustainable agricultural growth and food and nutrition security in Africa and India. Thomas Daum is also part of a research-project analysing the impacts of a smallholder mechanisation scheme in

Zambia, Kenya and Ghana. His research focuses on innovations and smallholders' mechanisation strategies that are sustainable from an economic, social and environmental perspectives. This involves research on governance and institutions, business models, time use and intra- household dynamics and Conservation Agriculture.

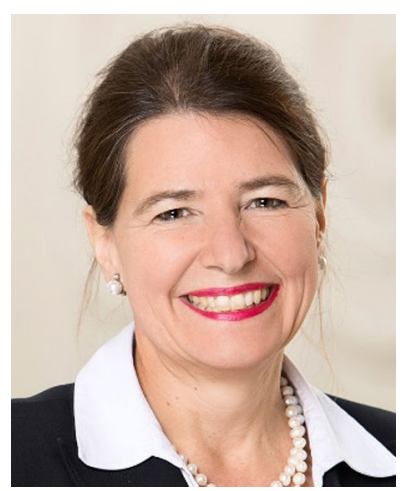

Prof. Dr. Regina Birner holds the Chair of Social and Institutional Change in Agricultural Development at the Institute of Agricultural Science in the Tropics (HansRuthenberg-Institute) at the University of Hohenheim, Germany. Her research focuses on the role of institutions in promoting agricultural development, with a focus on smallholder farming and sustainable natural resource management. Gender is a cross-cutting concern in her research. Regina Birner has extensive empirical research experience in Ghana and other developing countries, and has widely published in this field. She has previously worked at the International Food Policy Research Institute (IFPRI), and has consulted with international development organizations, such as the World Bank, the Food and Agriculture Organization (FAO), and the International Fund for Agricultural Development (IFAD). 